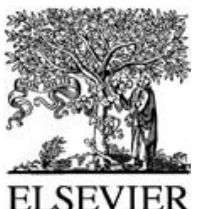

Available online at www.sciencedirect.com

science $\mathcal{d}$ DiREct

Library \& Information Science Research 28 (2006) 208-234

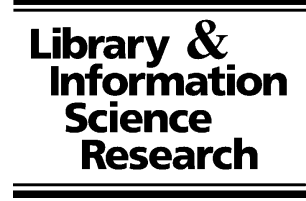

\title{
The self-publishing phenomenon and libraries
}

\author{
Juris Dilevko*, Keren Dali \\ Faculty of Information Studies, University of Toronto, Toronto, Ontario, Canada M5S 3G6 \\ Available online 4 May 2006
}

\begin{abstract}
In the late 1990s and early 2000s, the concept of book self-publishing for fiction and nonfiction began to loom large in the North American publishing universe. As traditional mainstream publishers consolidated and were often loathe to take chances on unknown writers whose books might not turn immediate profits, some authors found that fewer and fewer publishing venues were open to them. As a result, new self-publishers - collectively called "author services" or print-on-demand (POD) publishers - appeared alongside subsidy (or vanity) publishers. Against the background of an increasing corporatization of mainstream publishing, book self-publishing can theoretically be situated as one of the last bastions of independent publishing. This article examines how academic and public libraries dealt with the book self-publishing phenomena during 1960-2004. To what extent did libraries collect fiction and nonfiction published by self-publishing houses? Can any patterns be discerned in their collecting choices? Did libraries choose to collect more titles from "author services" publishers than subsidy publishers?
\end{abstract}

(C) 2006 Elsevier Inc. All rights reserved.

\section{Background}

Self-publishing of books has a long and illustrious history. Kremer (n.d.) has compiled an extensive list of now-famous authors who chose initially to self-publish their books or were forced to take this path because one or more of their books were rejected by one or more

\footnotetext{
* Corresponding author.

E-mail addresses: juris.dilevko@utoronto.ca (J. Dilevko), keren.dali@utoronto.ca (K. Dali).
} 
traditional publishers. Most of these authors undertook self-publishing without the help of formal self-publishing companies, contacting printers with whom they made a financial arrangement. Some authors even started their own presses. Among self-published authors are Margaret Atwood, William Blake, Elizabeth Barrett Browning, Willa Cather, W. E. B. DuBois, Benjamin Franklin, Nathaniel Hawthorne, Beatrix Potter, Mark Twain, Walt Whitman, and Virginia Woolf. More recently, Mawi Asgedom (Of Beetles and Angels), Dave Chilton (The Wealthy Barber), Irma Rombauer (The Joy of Cooking), and James Redfield (The Celestine Prophecy) enjoyed self-publishing success.

In North America, self-publishing evolved into a formal industry in the early and middle part of the twentieth century, with the growth of book subsidy (or vanity) publishers such as Dorrance Publishing (Pittsburgh, PA), founded in 1920, and Vantage Press (New York), founded in 1949. They typically used offset printing and charged an author between $\$ 8,000$ and $\$ 50,000$ "for a limited quantity of copies, some owned by the author and the rest warehoused" by the publisher (Glazer, 2005, p. 10). If Vantage Press can be taken as a representative example, each of these publishers produces "between 300 and 600 titles a year" (Glazer, 2005, p. 10), all the while warning authors that, although "[s]ome prestige and popularity may come your way ... it is important to recognize that you may only regain a small part of the fee" (Span, 2005, p. T8). All in all, these publishers never enjoyed stellar reputations, and were consistently on the sidelines of the publishing world.

The consolidation of mainstream publishing houses into corporate behemoths in the late 1990s meant that many formerly independent publishers became part of the entertainment divisions of profit-oriented companies answerable to shareholders, pension funds, and mutual funds. Once they became a part of these divisions, they were expected to show profits on each book they published (Schiffrin, 2000). Epstein (2001) explained that "[c]onglomerate budgets require efficiencies and create structures that are incompatible with the notorious vagaries of literary production, work whose outcome can only be intuited," adding that "the retail market for books is now dominated by a few large bookstore chains whose high operating costs demand high rates of turnover and therefore a constant supply of bestsellers, an impossible goal but one to which publishers have become perforce committed" (p. 12). One publishing official describes the situation in vivid terms: "Companies like Random House and Simon \& Schuster are in the process of investing in highly valuable properties. They want to find Deepak Chopra; they don't want to find a writer necessarily who has an audience of 10,000 people" (quoted in Glazer, 2005, p. 10). Conventional publishers - that is, publishers that do not concentrate on scholarly monographs - became risk-averse, concentrating their energies on books that they were confident would be guaranteed bestsellers and profit makers.

In this environment, many first-time authors - and even seasoned writers with one, two, or three published books - found it increasingly difficult to convince established publishers to take a chance on their new books. For example, Wyatt (2004) describes how Jeffrey Marx, a published Simon \& Schuster (S\&S) author, after having his idea for a new book (Seasons of Life) about "a former professional football player turned minister who teaches high school football players how to be men of substance" rejected by S\&S in 2003, finally secured a book contract with S\&S in late 2004, but only after he self-published and sold - through extensive entrepreneurial efforts that included travel, speeches, and self-generated publicity-14,000 
copies. In addition, university presses and small independent presses were paying more and more attention to financial questions - a circumstance that invariably meant that they took fewer chances on manuscripts whose sales potential they could not accurately gauge (Thompson, 2005).

It was in this context that a new generation of self-publishers such as AuthorHouse, iUniverse, and Xlibris developed in the middle and late 1990s. Often referred to as "author services" publishers and employing print-on-demand (POD) technology, they marketed themselves to the growing number of disaffected authors who had been frustrated by repeated rejections from corporate and independent publishers. iUniverse, for example, "print[s] a trade paperback for $\$ 299$ to $\$ 748$, depending on how many 'free' copies and how much 'editorial review' a customer wants, with additional charges for line-editing, proofreading and press releases" (Span, 2005, p. T8), assigns it an ISBN number, and makes it available to online book retailers (Glazer, 2005). Xlibris, in conjunction with Borders bookstores, offers a "take-home self-publishing kit" explaining that, "for between \$299 and \$598, customers can have a manuscript converted into a book by Xlibris, be listed on Amazon.com and get shelf space in Borders" (Glazer, 2005, p. 11). AuthorHouse, which began under the name of 1stBooks (or 1st Books), offers standard paperback publishing for $\$ 698$ and color paperback publishing for $\$ 999$, with a wide array of ancillary services, including a "Personal Media Valet" for $\$ 3,000$, “Expanded Promotion" for $\$ 750$, a “Booksellers Return Program" for $\$ 699$, and "Media Alerts" for $\$ 450$ (AuthorHouse, 2005, p. 8).

Although vehemently against being considered either a POD or subsidy publisher, PublishAmerica, which released 4,800 titles in 2004 (Span, 2005), was nevertheless part of the new wave of self-publishers (PublishAmerica, 2005). Despite offering authors a nominal $\$ 1$ advance, seven-year contracts, and royalties of $8 \%, 10 \%$, and $12.5 \%$ (depending on the number of copies sold), it soon garnered a negative reputation (Span, 2005). Whether this was warranted or not, it associated PublishAmerica with older subsidy models of self-publishing, although one of PublishAmerica's titles - Mary Carpenter's Rescued by a Cow and a Squeeze, a biography of Temple Grandin, a professor at Colorado State University who designs humane animal facilities - received a highly favorable review in 2003 in the prestigious Washington Post Book World.

The "author services" business model made an immediate impact. AuthorHouse had approximately 23,000 books under contract in early 2005; between its inception in 1997 and the end of 2003, it sold approximately 2 million titles (Glazer, 2005). In 2004, AuthorHouse, iUniverse, and Xlibris - considered to be the top three self-publishing firms - introduced "a total of 11,906 new titles" (Glazer, 2005, p. 10). And, in an attempt to escape the vanity press stigma and reach bookstore shelves, iUniverse introduced a program called "Star," which "select[s] two or three books a month that have passed an internal editorial review and sold more than 500 copies," offers them to bookstores at competitive discounts, accepts returns, and sends out advance galleys to reviewing outlets (Glazer, 2005, p. 11).

The impact of these companies was such that many established authors turned to selfpublishing "because they're unable to interest their publishers in a new genre" (Glazer, 2005, p. 11). This was the case with fantasy and science fiction author Piers Anthony, who, at the beginning of 2005, "ha[d] published more than 15 books with Xlibris, either to release serious 
historical fiction or to make out-of-print books available" (Glazer, 2005, p. 11). In perhaps the clearest sign that self-publishers such as AuthorHouse, iUniverse, and Xlibris had escaped the debilitating vanity press stigma, literary agents began to recommend to some best-selling authors that they publish with these companies. Kathryn Harvey was advised to publish her book Private Entrance with Xlibris because traditional mainstream publishers "complained that [it] ... fit into neither the 'chick-lit' category nor the older woman's audience (sometimes called 'hen lit')" (Glazer, 2005, p. 11). Harvey's agent summarized the new publishing landscape: "The self-publishing route has become a viable alternative for a lot of these authors who can't conveniently categorize what they're doing" (quoted in Glazer, 2005, p. 11). His implication was clear: mainstream publishers prefer proven and safe categories that have reliable sales records. As soon as something different appears, these publishers become reticent, fearing a lack of profits if they take a chance on an unproven commodity.

There is little dispute that the self-publishing of fiction and nonfiction books in North America grew in the late 1990s and early 2000s, mainly because of the POD model. Still, book self-publishers of all kinds continued to have what could best be described as mixed reputations because of the perceived poor quality of the books they publish and because - no matter the often complex contractual arrangements between the companies and authors authors themselves, in the final analysis, pay to have their works published. Indeed, the first factor is often seen as leading to the second. Thus, although there have been many bestselling self-published successes over the past decades and centuries, a stigma hovers over the book self-publishing universe - a stigma exacerbated by the controversy, in the early 2000s, involving PublishAmerica, which stood accused of a wide range of deceptive practices (Span, 2005). As a result, many newspapers, including the New York Times, have longstanding policies whereby they do not review books published by self-publishers (Glazer, 2005). In addition, bookstores are typically "reluctant to stock self-published books . . . because they carry the vanity press taint, they aren't returnable and they aren't discounted as much as traditional books" (Glazer, 2005, p. 10).

\section{Libraries and self-publishers}

In public and academic libraries, there has been, for the most part, an awkward silence about how to deal with books from self-publishers, mainly because of the lack of reviews of self-published books in mainstream reviewing outlets. But, as the nature of publishing changes by taking on myriad electronic manifestations and as libraries begin to come to terms with the philosophies and concepts underlying electronic publishing and collection development, the issue of whether to collect self-published books assumes importance.

The first statement about the importance of self-published books for library collections appeared in 1984 (Hayward, 1992). Crook and Wise (1987), two proponents of selfpublishing, in explaining that self-publishers should target libraries as potential customers, observed that libraries "have little prejudice against self-published books," mainly because, as Kremer (1986) pointed out, they are "information specialists ... continually and actively seeking new titles which can help them better serve their library patrons" (quoted in Hayward, 
1992, p. 290). Hayward (1992) remarked that libraries should make a concerted effort to collect self-published books because "[g]ood writers are writing and publishing good books on specialized subjects that trade publishers will no longer produce because of the limited financial returns possible on these books" (p. 290).

The enthusiasm of the 1980s and early 1990s soon gave way to a harsher view. Manley (1999) may be seen as having a realistic attitude towards self-publishers. He lamented that librarians and reviewers are often inundated with "poorly xeroxed cop[ies] of an announcement of a new book" that a "true-believer" author has published himself (p. 485). These books are typically either "a personal testimony of someone who has seen God, survived a terminal disease, fought in a war, or met an alien coming out of a flying saucer; a technical treatise on something obscure like a two-phased parachute, a four-barreled carburetor, or an eight-sided kite; the history of an inconsequential sports team, religious sect, educational institution, or residential community; or a conspiracy theory imputing evil intent to the U.S. government, the British royal family, or the Chinese Mafia" (p. 485). He noted the "brutal reality" that almost $100 \%$ of self-published books "have been rejected by mainstream publishers for one of two reasons: the book is a poorly written piece of drivel, or the book is on a subject that no one cares about with the possible exception of an author's family and his two best friends" ( $\mathrm{p}$. 485). Still, he identified one exception to his general comments-The Prison Called Hohenasperg: An American Boy Betrayed by His Government during World War II by Arthur D. Jacobs - and suggested that "[o]ur standard line that a book must merit at least one positive review from a reputable source can be rather tyrannical in that rare instance when a self-published book does represent an important contribution to a valid subject area" (p. 485).

Manley's (1999) ambiguous stance with regard to self-publishers-consider the cumulative negative effect of his use of the adjectives "rare," "important," and "valid" in his article - has echoed the debate about whether libraries should collect zines, another major form of self-publishing. While Bartel (2003), Herrada (1995), and Stoddart and Kiser (2004) stressed the importance of establishing zine collections in public and academic libraries, the ephemeral nature of zines - not to mention the cataloging and preservation problems they represent - was a factor in the disinclination of many libraries to start collecting them. In broad terms, faced with an overwhelming number of books published by well-known corporate and independent publishers, on the one hand, and tighter and tighter budgets on the other, librarians may not consider self-publishing companies and their products to be worthy of attention, especially given Manley's (1999) statement that "99.99 percent" of selfpublished books are "drivel" (p. 485).

\section{Problem statement and research questions}

Given the rapid growth of book self-publishing, as well as the fraught reputation of selfpublishers, how have academic and public libraries dealt with the issue of self-published books in the years 1960-2004, as represented by the number and range of books published by self-publishers appearing in their catalog records and hence on their shelves? A word about the vocabulary used here. The terms "title" and "book" are used synonymously in the 
remainder of this article. The Online Computer Library Center (OCLC) defines titles as a "[t]erm(s) used to name a library resource such as a book, article, transcript, video, recording, song, score, or software" (Online Computer Library Center, 2005a). But, as will be seen below, 99.99\% of titles produced by the self-publishers studied in the present article are books. In addition, libraries that own a copy of a specific title are referred to as "holding libraries," or a sentence such as "the library held a particular title" is used.

Six research questions were posited:

1. To what extent are libraries in the United States and Canada choosing to collect selfpublisher titles? That is, how many titles published by self-publishers appear in the catalog records of libraries?

2. Are libraries in general choosing to collect more titles from one self-publisher than from another?

3. Are there identifiable trends in library holdings with regard to subsidy self-publishers and "author services" self-publishers in library holdings?

4. Which types of titles covering which subject areas from which self-publishers are libraries choosing to collect the most?

5. Do different types of libraries collect (i.e., hold) different types of titles from selfpublishers?

6. What percentage of self-published titles are held collectively and individually by major public and academic libraries?

\section{Procedures}

From the hundreds of self-publishers in the United States and Canada, seven selfpublishers were identified for further study. These seven were all mentioned in two prominent articles dealing with the self-publishing phenomena during 2005 (Glazer, 2005; Span, 2005). As such, they represent a good cross-section of what is understood, in the public mind, to be a self-publisher. Three were subsidy publishers: Dorrance Publishing, Ivy House, and Vantage Press. Four were "author services" publishers: AuthorHouse/1st Books/1stBooks (hereafter referred to as AuthorHouse), iUniverse, PublishAmerica, and Xlibris. In this latter category, AuthorHouse, iUniverse, and Xlibris are POD publishers, while PublishAmerica wants to distance itself from the POD designation (PublishAmerica, 2005).

Using WorldCat Advanced Search, an online database developed and maintained by OCLC, the investigators searched by the individual publisher name (and likely variants to take into account cataloging entry errors) as mentioned above and, where applicable, by publisher location. All searches were carried out in a three-week period in May-June 2005 and updated on June 13, 2005. Searches were meant to elicit both the raw number of total titles published by each self-publishing company that were held by all libraries participating in the OCLC consortium, as well as the names of the top 25 titles published by each selfpublishing company that were held by all libraries in the OCLC consortium and the number of libraries holding these top 25 titles. For Dorrance Publishing and Vantage Press - the two 
oldest self-publishers in the set of seven-searches covered 1960-2004. For the five other publishers - all of which were founded in the middle and late 1990s - searches covered the years 2000-2004. The researchers also asked WorldCat to generate a frequency distribution of how many OCLC-member libraries owned a particular title published by each of the seven self-publishers.

The names of the libraries holding the top 25 titles published by each of the seven selfpublishers were downloaded from WorldCat using the feature called "Display All Libraries." In the interests of completeness, the feature called "Find Books with Same Title and Author" was also used. When this feature generated additional records corresponding to the titles in the top 25 list, these records were included in the statistics reported in the present article, but only if they were published by the same self-publisher as in the original set of records. The output for the "Display All Libraries" records comes in the form of alphabetical state-by-state lists of all OCLC-member libraries possessing at least one copy of a particular title.

Each of the top 25 titles from each of the seven self-publishers was then categorized according to its subject matter and form of publication based on the Library of Congress (LC) and/or Dewey classification numbers and/or LC subject headings found in the OCLC catalog records. Broad subjects and forms were assigned using LC classification schedules and subject headings. Subject categories with only one title were combined with a closely related area; for instance, the one title about the history of Canada was combined with titles about the history of the United States to form a subject category called history of the United States and Canada.

In addition, the libraries that held the top 25 titles from the seven self-publishers were classified according to the following nine-fold categorization: university library, which included libraries belonging to medical schools and law schools; college library, which included libraries pertaining to seminaries and religious colleges; community college library, which included libraries at technical colleges and junior colleges; public library, which included public library consortia and school libraries; military library, which included libraries at military bases, military institutions of higher learning, and Veterans Affairs medical centers; government library, which included national depository libraries and libraries belonging to nonmilitary departments of national government entities; state library; a library belonging to a historical society, museum, archives, or art gallery; and other library, which included private corporations, law firms, banks, churches, and nonmilitary hospitals. OCLC provides a one-line identifier for each holding library; this identifier typically contains either the full name of the holding institution or abbreviations such as UNIV, COL, COMMUN COL, PUB, CNTY, REG, MIL, and others that make the categorization straightforward. In those cases where there was any doubt about which category a library belonged to - for example, all institutions designated as COL were checked in order to make sure whether they were in fact universities, colleges, or community colleges - the library name was searched using Web sites and an ultimate categorization was decided.

To determine the extent to which major academic libraries held titles published by the seven selected self-publishers, the researchers used the 2003 list of top-ranked academic library systems (the most recent available at the time this research was conducted) as published by the Association of Research Libraries (2005) (ARL) on its Web site. The researchers picked the 25 top-ranked ARL library systems in the United States and searched for the three-letter 
institutional code of each system's main library in OCLC's "Find Codes for Participating Institutions" feature. Entering these 25 codes as a group in the "limit by library code" box on the WorldCat search screen, the researchers asked WorldCat to generate the raw number of titles published by the seven self-publishers that were held by the main libraries of the 25 top-ranking ARL library systems. This procedure was repeated with public libraries, this time using a list of the top 25 public library systems (ranked according to holdings) from Statistical Report 2004 (Public Library Association, 2004). Finally, the researchers selected the top five ARL library systems (not from the same state) and the top five public libraries (not from the same state) and repeated these procedures using each of their institutional codes separately. Taken together, these procedures allowed the researchers to gauge the degree to which major academic and public libraries in the United States held titles published by the selected seven self-publishers.

The methodology is subject to all the limitations encountered when working with bibliographical databases administered by OCLC. While over 9000 libraries - most in the United States and Canada - belong to OCLC and while OCLC has over 58 million records (Online Computer Library Center, 2005b), not all libraries in North America are members of OCLC and thus do not contribute records. Many libraries that are not OCLC members may therefore have extensive collections of books published by self-publishers. In addition, OCLC records do not indicate how many copies of a specific title a reporting library has. A large metropolitan or regional library system with many branches may report as a single system holding a single copy of a particular self-published title though its various branches hold, say, 20 copies of that title. Another large central system may have a policy whereby its branches report separately. The presence of bibliographic records in OCLC is also dependent on the speed with which participating institutions enter information about their holdings. Institutions with backlogged cataloging departments yield an underestimation of OCLC cumulative statistics. Finally, when catalogers use OCLC to download records to their individual institutional catalogs, they may neglect to update cumulative OCLC holding statistics, which necessitates an extra step. These factors may result in an underreporting of self-publisher titles in libraries. Finally, the research presented here is necessarily a snapshot of an evolving picture, since OCLC updates its database frequently. The reported findings are therefore best viewed as broad trends.

\section{Results}

The first three research questions are addressed in Section 5.1. Research question four is addressed in Section 5.2. Research question five is addressed in Section 5.3. Research question six is addressed in Section 5.4.

\subsection{Self-publishers in North American libraries}

OCLC-member libraries held 14,061 titles that were published in 2000-2004 by the seven self-publishers, with 14,042 of these titles (99.99\%) identified as books by OCLC. As shown in Table 1, titles published by AuthorHouse (5223), Xlibris (3351), and iUniverse (2945) are 
Table 1

Number of titles published by seven American self-publishers (2000-2004) held by OCLC-member libraries

\begin{tabular}{lcr}
\hline Publisher & No. of titles & $\%$ \\
\hline AuthorHouse & 5223 & 37.1 \\
Dorrance & 525 & 3.7 \\
iUniverse & 2945 & 20.9 \\
Ivy House & 69 & 0.5 \\
PublishAmerica & 1250 & 8.9 \\
Vantage Press & 698 & 5.0 \\
Xlibris & 3351 & 23.8 \\
Total & 14,061 & 100 \\
\hline
\end{tabular}

Percentages do not add to 100 due to rounding.

the most widely held in OCLC-member libraries. If total number of titles held from a publisher is conceived as a measure of publisher reputation in the library world, then AuthorHouse leads the way, with $37.1 \%$ of all titles held, followed by Xlibris $(23.8 \%)$ and iUniverse (20.9\%). Titles published by PublishAmerica (1250) and each of the three subsidy publishers - Dorrance, Ivy House, and Vantage Press - are held at substantially lower rates.

However, if another measure of publisher reputation is looked at - that is, the number of OCLCmember libraries that hold the top 25 overall held titles from the seven self-publishers - a slightly different picture emerges from that in Table 1. As shown in Table 2, Xlibris titles are held by the largest number of OCLC-member libraries (2589), followed by iUniverse (1998) and AuthorHouse (1905). In percentage terms, Xlibris titles account for $29 \%$ of the holdings of OCLC-member libraries in terms of the overall top 25 held titles published by the seven self-publishers; AuthorHouse is at $21.3 \%$, slightly behind iUniverse (22.4\%). Findings from Table 2 are given credence by data in Table 3: of the top 10 self-published titles (2000-2004) held by OCLC-member libraries, Xlibris published four, iUniverse three, AuthorHouse two, and Vantage Press one.

The 14,061 total self-published titles are not broadly held across OCLC-member libraries. As Table 4 shows, there is a pyramid effect in the distribution of self-publisher titles: $42.8 \%$ of the titles are held by only one OCLC-member library each, while another $38.6 \%$ of the titles are held by 2-4 OCLC-member libraries, and 12\% are held by 5-9 OCLC-member libraries. In other words, $93.4 \%$ of the titles from self-publishers are held by fewer than 10

Table 2

Number of OCLC-member libraries holding top 25 overall held titles from seven American self-publishers

\begin{tabular}{lcr}
\hline Publisher & No. of libraries & $\%$ \\
\hline AuthorHouse & 1905 & 21.3 \\
Dorrance & 462 & 5.2 \\
iUniverse & 1998 & 22.4 \\
Ivy House & 316 & 3.5 \\
PublishAmerica & 676 & 7.6 \\
Vantage Press & 989 & 11.1 \\
Xlibris & 2589 & 29.0 \\
Total & 8935 & 100 \\
\hline
\end{tabular}

Percentages do not add to 100 due to rounding. 
Table 3

Top 10 titles published by seven American self-publishers ranked by the number of OCLC-member libraries holding these titles

\begin{tabular}{|c|c|c|c|}
\hline Rank & Title (Author) & Publisher & $\begin{array}{l}\text { No. of libraries } \\
\text { holding title }\end{array}$ \\
\hline 1 & $\begin{array}{l}\text { Abortion and Common Sense } \\
\text { (Ruth Dixon-Mueller and } \\
\text { Paul K. B. Dagg) }\end{array}$ & Xlibris & 483 \\
\hline 2 & $\begin{array}{l}\text { If I Knew then ... } \\
\text { (Amy Fisher and Robbie } \\
\text { Woliver) }\end{array}$ & iUniverse & 459 \\
\hline 3 & $\begin{array}{l}\text { American Western Song: } \\
\text { Poems from } 1976 \text { to } 2001 \\
\text { (Victor W. Pear) }\end{array}$ & Xlibris & 403 \\
\hline 4 & $\begin{array}{l}\text { Lewis and Clark in the } \\
\text { Illinois Country: The Little } \\
\text { Told Story (Robert E. Hartley) }\end{array}$ & Xlibris & 224 \\
\hline 5 & $\begin{array}{l}\text { Dancing with Mosquitoes: } \\
\text { To Liberate the Mind from } \\
\text { Humanism (Theo Grutter) }\end{array}$ & Vantage Press & 222 \\
\hline 6 & $\begin{array}{l}\text { The Guide to Identity Theft } \\
\text { Protection (Johnny R. May) }\end{array}$ & AuthorHouse & 217 \\
\hline 7 & $\begin{array}{l}\text { The Russian Adoption } \\
\text { Handbook (John H. Maclean) }\end{array}$ & iUniverse & 201 \\
\hline 8 & $\begin{array}{l}\text { The Chinese Adoption } \\
\text { Handbook (John H. Maclean) }\end{array}$ & iUniverse & 194 \\
\hline 9 & $\begin{array}{l}\text { "Misty": First Person Stories } \\
\text { of the F-100 Misty (Don Shepperd) }\end{array}$ & AuthorHouse & 174 \\
\hline 10 & $\begin{array}{l}\text { Race and the Rise of the } \\
\text { Republican Party, 1848-1865 } \\
\text { (James D. Bilotta) }\end{array}$ & Xlibris & 155 \\
\hline
\end{tabular}

OCLC-member libraries each. Only 822 titles $(5.8 \%)$ are held by 10 or more OCLC-member libraries each, and only 61 titles (less than $1 \%$ ) are held by 50 or more OCLC-member libraries each. Only 14 titles are held by 100 or more OCLC-member libraries each, with 12 of these 14 titles published by AuthorHouse, iUniverse, or Xlibris. Only three titles are held by 400 or more OCLC-member libraries each, and all three of these are published by iUniverse (1) and Xlibris (2).

Can the arrival of "author services" self-publishers in the late 1990s and 2000s be associated with a decline in the holdings of subsidy publishers by OCLC-member libraries? As shown in Table 5, the answer is mixed. Vantage Press titles that were published in each of the two fiveyear increments between 1995 and 2004 are held by fewer OCLC-member libraries than Vantage Press titles published in each of the five-year increments between 1965 and 1994. On the other hand, Dorrance titles published in the two five-year increments between 1995 and 2004 are held by more OCLC-member libraries than Dorrance titles published in each of the five-year increments between 1960 and 1994, with the exception of the periods 1970-1974 and 1975-1979. However, in no five-year increment between 1960 and 2004 did OCLC-member 


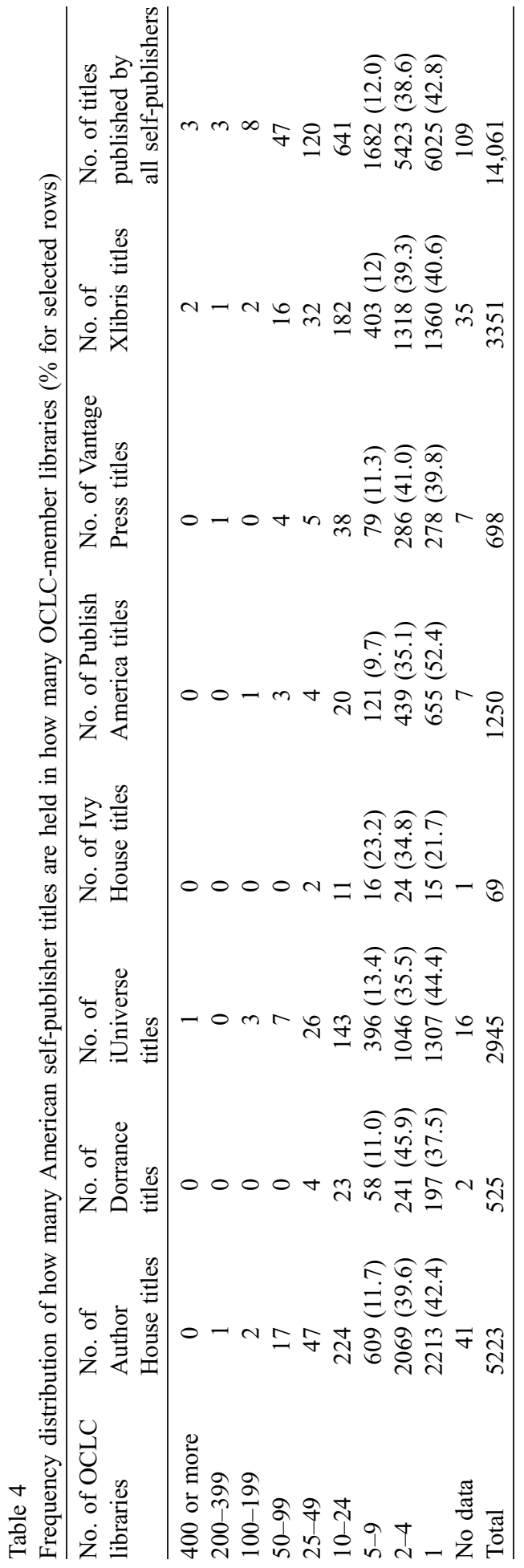


Table 5

Number of titles held by OCLC-member libraries that were published by Dorrance and Vantage Press in five-year increments (1960-2005)

\begin{tabular}{llc}
\hline & No. of Dorrance titles & No. of Vantage Press titles \\
\hline $2000-2004$ & 525 & 698 \\
$1995-1999$ & 618 & 1192 \\
$1990-1994$ & 334 & 1608 \\
$1985-1989$ & 168 & 1404 \\
$1980-1984$ & 249 & 1269 \\
$1975-1979$ & 548 & 1911 \\
$1970-1974$ & 671 & 1493 \\
$1965-1969$ & 329 & 1208 \\
$1960-1964$ & 182 & 927 \\
\hline
\end{tabular}

libraries choose to collect as many titles from Vantage or Dorrance as they did in the five-year increment 2000-2004 from each of the three principal "author services" publishers (AuthorHouse, iUniverse, and Xlibris).

Does the picture change when the extent to which individual Dorrance and Vantage Press titles are held by OCLC-member libraries is examined? During 1960-1999, both Dorrance and Vantage Press had many titles that were held by more than 200 OCLCmember libraries each. For example, 14 Dorrance titles published between 1960 and 1999 were in more than 200 OCLC-member libraries each, including The Moral Foundations of United States Constitutional Democracy (1992) (229 libraries), Black Mathematicians and Their Works (1980) (268 libraries), The Navajo Code Talkers (1973) (450 libraries), Ruth Suckow: A Critical Study of Her Fiction (1972) (246 libraries), and Chaucer and the Liturgy (1967) (284 libraries). Twenty-seven Vantage Press titles published between 1960 and 1999 were in more than 200 OCLC-member libraries each, including Opera as Dramatic Poetry (1993) (535 libraries), The Inventor's Handbook on Patent Applications (1993) (279 libraries), The Human Vocal Tract: Anatomy, Function, Development, and Evolution (1987) (471 libraries), The Hatch Act and the American Bureaucracy (1981) (250 libraries), American Cut Glass for the Discriminating Collector (1965) (421 libraries), and The United Colonies of New England, 1643-1690 (1961) (614 libraries). Conversely, in 2000-2004, Dorrance does not have a single title that is held by more than 50 OCLCmember libraries, while Vantage Press has only one title held by more than 50 OCLCmember libraries (Dancing with Mosquitoes, held by 222 libraries). If the number of OCLC-member libraries holding a specific title is an indication of the quality of that title, then the quality of Dorrance and Vantage Press publications declined when comparing the period of 1960-1999 with 2000-2004.

\subsection{Types of titles collected}

As shown in Table 6, the type of title that OCLC-member libraries collect the most (26.3\%) from self-publishers is handbooks, manuals, guidebooks, and self-help titles (based on the 25 titles held the most in OCLC-member libraries from each of the seven self- 


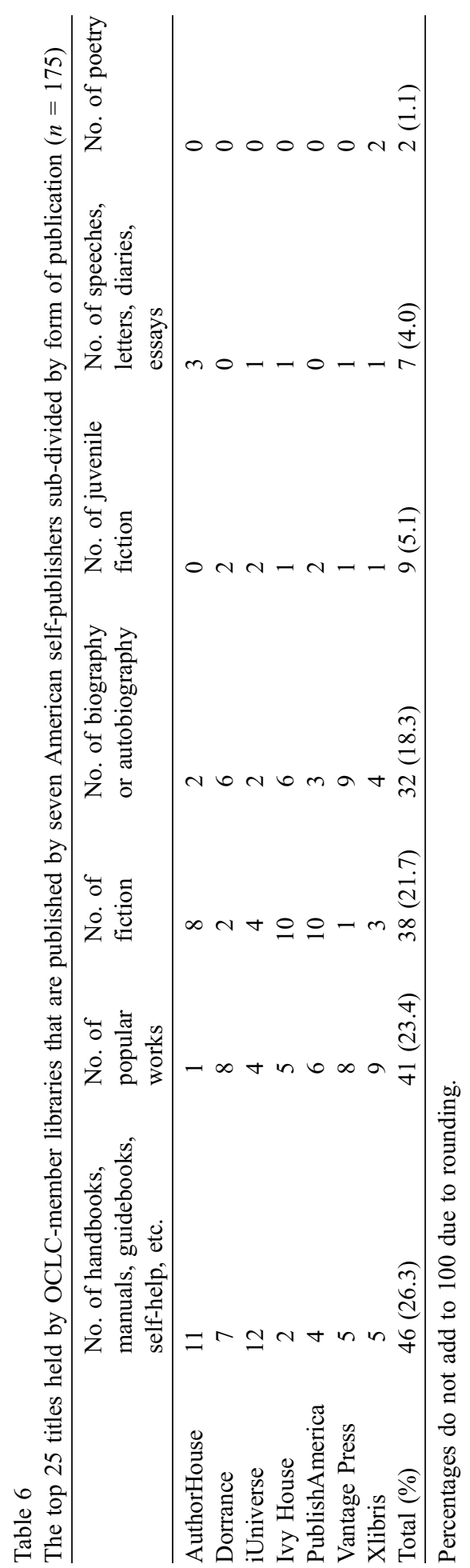


publishers). The "handbooks and manuals" category includes life skills guides, study guides, textbooks, self-instruction books, directories, indexes, and so on. "Popular works"-defined as nonfiction monographs written on subjects such as history, medicine, technology, and science for nonspecialist readers - was the second most popular category (23.4\%), followed by fiction (21.7\%) and "biography or autobiography" (18.3\%). Table 6 also shows that there are substantial differences in the types of titles each of the seven self-publishers publishes that are widely held in OCLC-member libraries. Almost half of the top 25 titles held in OCLCmember libraries published by AuthorHouse (11) and iUniverse (12) fall in the "handbook and manuals" category. PublishAmerica and Ivy House seem to be making their mark with fiction (10), Vantage Press with "biography or autobiography" (9), and Xlibris with "popular works" (9).

These holdings data also suggest that iUniverse is more dependent for its presence in OCLC-member libraries on a single category of title ("handbooks and manuals"-12) than any of the other self-publishers. For instance, while AuthorHouse does have 11 "handbooks and manuals" in its overall top 25 held titles by OCLC-member libraries, it also has 8 fiction titles. Similarly, while PublishAmerica has 10 fiction titles in its overall top 25 held

Table 7

Subjects covered by the nonfiction titles among the top 25 titles held by OCLC-member libraries and published by seven American self-publishers $(n=126)$

\begin{tabular}{|c|c|c|c|c|c|}
\hline & $\begin{array}{l}\text { No. of } \\
\text { handbooks, } \\
\text { manuals, } \\
\text { guidebooks, } \\
\text { self-help, etc. }\end{array}$ & $\begin{array}{l}\text { No. of } \\
\text { popular } \\
\text { works }\end{array}$ & $\begin{array}{l}\text { No. of biography } \\
\text { or autobiography }\end{array}$ & $\begin{array}{l}\text { No. of speeches, } \\
\text { letters, diaries, } \\
\text { essays }\end{array}$ & $\begin{array}{l}\text { Total } \\
\text { no. }\end{array}$ \\
\hline Social sciences & 13 & 4 & 2 & 0 & 19 \\
\hline $\begin{array}{l}\text { History of the United } \\
\text { States and Canada }\end{array}$ & 1 & 7 & 9 & 1 & 18 \\
\hline Medicine & 10 & 3 & 5 & 0 & 18 \\
\hline $\begin{array}{l}\text { Political sciences, } \\
\text { education, and law }\end{array}$ & 5 & 2 & 2 & 3 & 12 \\
\hline Science & 2 & 5 & 2 & 0 & 9 \\
\hline Religion and theology & 1 & 5 & 1 & 1 & 8 \\
\hline History of Europe & 0 & 4 & 1 & 1 & 6 \\
\hline Technology & 4 & 2 & 0 & 0 & 6 \\
\hline Fine arts and music & 1 & 1 & 2 & 1 & 5 \\
\hline $\begin{array}{l}\text { Geography, anthropology, } \\
\text { and recreation }\end{array}$ & 3 & 1 & 1 & 0 & 5 \\
\hline History of Asia & 0 & 2 & 3 & 0 & 5 \\
\hline Psychology & 3 & 1 & 0 & 0 & 4 \\
\hline Agriculture & 1 & 1 & 1 & 0 & 3 \\
\hline $\begin{array}{l}\text { Literature-biography } \\
\text { and criticism }\end{array}$ & 0 & 2 & 1 & 0 & 3 \\
\hline Military and naval sciences & 1 & 1 & 1 & 0 & 3 \\
\hline Library and information science & 1 & 0 & 1 & 0 & 2 \\
\hline Total & 46 & 41 & 32 & 7 & 126 \\
\hline
\end{tabular}


Table 8

Number of OCLC-member libraries holding copies of the top 25 titles published by American self-publishers subdivided by subject $(n=8935)$

\begin{tabular}{|c|c|c|c|c|c|c|c|c|}
\hline & $\begin{array}{l}\text { No. of } \\
\text { Author } \\
\text { House } \\
\text { titles }\end{array}$ & $\begin{array}{l}\text { No. of } \\
\text { Dorrance } \\
\text { titles }\end{array}$ & $\begin{array}{l}\text { No. of } \\
\text { iUniverse } \\
\text { titles }\end{array}$ & $\begin{array}{l}\text { No. of } \\
\text { Ivy } \\
\text { House } \\
\text { titles }\end{array}$ & $\begin{array}{l}\text { No. of } \\
\text { Publish } \\
\text { America } \\
\text { titles }\end{array}$ & $\begin{array}{l}\text { No. of } \\
\text { Vantage } \\
\text { Press } \\
\text { titles }\end{array}$ & $\begin{array}{l}\text { No. of } \\
\text { Xlibris } \\
\text { titles }\end{array}$ & $\begin{array}{l}\text { Subject } \\
\text { total } \\
\text { no. }(\%)\end{array}$ \\
\hline Social sciences & 419 & 0 & 1033 & 7 & 63 & 15 & 668 & $\begin{array}{r}2205 \\
(24.7)\end{array}$ \\
\hline Fiction & 495 & 23 & 218 & 88 & 211 & 83 & 215 & $\begin{array}{r}1333 \\
(14.9)\end{array}$ \\
\hline $\begin{array}{l}\text { History of the } \\
\text { United States } \\
\text { and Canada }\end{array}$ & 79 & 14 & 34 & 79 & 144 & 126 & 422 & $\begin{array}{r}898 \\
(10.1)\end{array}$ \\
\hline $\begin{array}{l}\text { Political sciences, } \\
\text { education, and law }\end{array}$ & 288 & 0 & 307 & 76 & 0 & 25 & 0 & $\begin{array}{r}696 \\
(7.8)\end{array}$ \\
\hline Medicine & 183 & 62 & 36 & 12 & 42 & 146 & 176 & $\begin{array}{r}657 \\
(7.4)\end{array}$ \\
\hline Science & 0 & 41 & 96 & 0 & 0 & 341 & 0 & $\begin{array}{r}478 \\
(5.4)\end{array}$ \\
\hline Poetry & 0 & 0 & 0 & 0 & 0 & 0 & 450 & $\begin{array}{r}450 \\
(5.0)\end{array}$ \\
\hline $\begin{array}{l}\text { Religion and } \\
\text { theology }\end{array}$ & 138 & 83 & 0 & 12 & 86 & 0 & 0 & $\begin{array}{r}319 \\
(3.6)\end{array}$ \\
\hline Juvenile fiction & 0 & 29 & 89 & 5 & 52 & 23 & 61 & $\begin{array}{r}259 \\
(2.9)\end{array}$ \\
\hline History of Europe & 0 & 0 & 0 & 29 & 10 & 91 & 113 & $\begin{array}{r}243 \\
(2.7)\end{array}$ \\
\hline History of Asia & 174 & 26 & 0 & 0 & 0 & 32 & 0 & $\begin{array}{r}232 \\
(2.6)\end{array}$ \\
\hline Fine arts and music & 0 & 0 & 34 & 0 & 0 & 36 & 155 & $\begin{array}{r}225 \\
(2.5)\end{array}$ \\
\hline $\begin{array}{l}\text { Geography, } \\
\text { anthropology, } \\
\text { and recreation }\end{array}$ & 76 & 30 & 0 & 0 & 0 & 21 & 57 & $\begin{array}{r}184 \\
(2.1)\end{array}$ \\
\hline Technology & 53 & 59 & 0 & 0 & 34 & 15 & 0 & $\begin{array}{r}161 \\
(1.8)\end{array}$ \\
\hline Psychology & 0 & 18 & 0 & 0 & 34 & 0 & 100 & $\begin{array}{r}152 \\
(1.7)\end{array}$ \\
\hline $\begin{array}{l}\text { Library and } \\
\text { information science }\end{array}$ & 0 & 0 & 116 & 0 & 0 & 35 & 0 & $\begin{array}{r}151 \\
(1.7)\end{array}$ \\
\hline Agriculture & 0 & 27 & 35 & 0 & 0 & 0 & 60 & $\begin{array}{r}122 \\
(1.4)\end{array}$ \\
\hline $\begin{array}{l}\text { Military and naval } \\
\text { sciences }\end{array}$ & 0 & 16 & 0 & 8 & 0 & 0 & 64 & $\begin{array}{r}88 \\
(1.0)\end{array}$ \\
\hline $\begin{array}{l}\text { Literature - biography } \\
\text { and criticism }\end{array}$ & 0 & 34 & 0 & 0 & 0 & 0 & 48 & $\begin{array}{r}82 \\
(0.9)\end{array}$ \\
\hline $\begin{array}{l}\text { Publisher total } \\
\text { no. }(\%)\end{array}$ & $\begin{array}{r}1905 \\
(21.3)\end{array}$ & $\begin{array}{r}462 \\
(5.2)\end{array}$ & $\begin{array}{l}1998 \\
(22.4)\end{array}$ & $\begin{array}{r}316 \\
(3.5)\end{array}$ & $\begin{array}{r}676 \\
(7.6)\end{array}$ & $\begin{array}{r}989 \\
(11.1)\end{array}$ & $\begin{array}{c}2589 \\
(29.0)\end{array}$ & $\begin{array}{l}8935 \\
(100)\end{array}$ \\
\hline
\end{tabular}

Percentages do not add to 100 due to rounding. 
titles, it also has 6 titles categorized as "popular works." The most diverse and wide-ranging self-publisher is Xlibris, the only self-publisher with titles in all identified categories.

As shown in Table 7, which looks only at nonfiction titles, exactly half of the "handbooks and manuals" category is composed of social sciences (13) and medicine (10) titles, while the categories of "popular works" and "biography or autobiography" have numerous titles falling within the field of history, especially the history of the United States and Canada (7), but also history of Europe (4) and history of Asia (2). The "social sciences" category includes such topics as commerce and business, office management and retail trade, labor, criminology, and family issues. Overall, the three most popular nonfiction (and nonpoetry) subjects published by self-publishers and held in OCLC-member libraries are the social sciences (19), history of the United States and Canada (18), and medicine (18).

Table 8 blends some of the findings of Tables 6 and 7 to provide a more detailed picture of the differences in the way OCLC-member libraries collect books from different selfpublishers, this time from the perspective of subject matter. When OCLC-member libraries hold titles from self-publishers in the broad field of social sciences, almost half of such titles come from iUniverse (1033 out of 2205 , or $46.8 \%$ ). In much the same way, when OCLCmember libraries hold titles from self-publishers in the field of history of the United States and Canada, almost half of such titles come from Xlibris (422 out of 898 , or $47 \%$ ). Table 8 also reiterates a finding from Table 6: iUniverse seems to be the most one-dimensional of the self-publishers discussed here. Slightly more than half of its overall top 25 held titles are in the social sciences (1033 out of 1998, or 51.7\%). No other self-publisher is as dependent on a single category as iUniverse for the presence of its titles in OCLC-member libraries, although PublishAmerica, with 211 held fiction titles out of 676 total held titles (31.2\%), is moving in a similar direction. On the other hand, both AuthorHouse and Xlibris have a broad subject range of titles in OCLC-member libraries.

\subsection{Types of libraries collecting self-publisher titles}

As shown in Table 9, in terms of the number of OCLC-member libraries holding the overall top 25 held titles published by each of the seven American self-publishers, 5,150 OCLC-member public libraries hold self-published titles (57.6\%), more than double (2.56 times) the number of OCLC-member university libraries (2008 or 22.5\%) and about eight times the number of OCLC-member community college libraries (646 or 7.2\%) or OCLCmember college libraries (569 or 6.4\%). Much further down the list are OCLC-member military-related institutions ( 252 or $2.8 \%$ ) and OCLC-member libraries grouped under the rubric of "historical society" (69 or $0.8 \%$ ).

Different types of OCLC-member libraries have varying degrees of emphasis with regard to their holdings of different types of publications (Table 10), subject matter of publications (Table 11), and different self-publishers (Table 12). As shown in Table 10, while the number of OCLC-member libraries which hold self-publisher "handbooks and manuals" (28.4\%) and "popular works" (25.8\%) is about the same, public libraries account for $65.7 \%$ (1,667 out of 2536) of the total number of held "handbooks and manuals." Similarly, public libraries account for $62.3 \%$ of the total number of held "biographies or autobiographies" (1050 out of 1685 ) and $79.7 \%$ of the total of held fiction titles from 
self-publishers (1062 out of 1333). Universities, community colleges, and colleges, taken together, account for $62 \%$ of the total number of held "popular works," many of which, as shown in Table 7 , are histories of the United States, Europe, and Asia.

As seen in Table 9, OCLC-member public libraries hold 2.56 times the total number of selfpublisher titles than OCLC-member university libraries. If 2.56:1 is taken as a benchmark ratio, it is easy to identify the subject areas that, for public libraries, significantly exceed this ratio, or, for university libraries, invert this ratio, thus pinpointing subject areas that are of particular importance for a particular type of library. Thus, as shown in Table 11, OCLCmember public libraries hold 4.8 times as many self-publisher social sciences titles as OCLCmember university libraries, 6.6 times as many self-publisher technology titles, 6.9 times as many self-publisher fiction titles, 7.8 times as many "geography, anthropology, and recreation" titles, and 83 times as many juvenile fiction titles. Conversely, OCLC-member university libraries hold 1.1 times as many "fine arts and music" self-publisher titles as OCLC-member public libraries, 1.3 times as many "religion and theology" self-publisher titles, 1.8 times as many European history self-publisher titles, 2.6 times as many "political sciences, education, and law" titles, and 9.6 times as many "library and information science" self-publisher titles. These divergences from the benchmark ratio show that OCLC-public and university libraries are collecting self-publisher titles that appeal the most to their respective user groups. This is even more apparent in the case of military-related OCLC-member libraries. Of the 252 OCLCmember military-related libraries that hold self-publisher titles, 169 hold titles dealing with the history of Asia - an umbrella subject grouping that includes personal accounts of the Korean and Vietnam wars, among other topics.

As shown in Table 12, iUniverse titles are held most often by OCLC-member public libraries (in 1518 libraries), closely followed by Xlibris titles (in 1327 libraries). The picture changes in OCLC-member university, community college, and college libraries, where Xlibris titles are held most often (in 654, 285, and 218 libraries, respectively), followed by AuthorHouse titles (in 448, 164, and 128 libraries, respectively). In OCLC-member militaryrelated libraries, AuthorHouse titles are the most frequently held titles (in 177 libraries). In many ways, results shown in Table 12 reiterate findings from Table 8 . While iUniverse titles are concentrated at the rate of $76 \%$ (1518 out of 1998 total titles) in OCLC-member public libraries and PublishAmerica titles are concentrated in OCLC-member public libraries at a rate of $79.1 \%$ ( 535 out of 676 total titles), titles published by AuthorHouse and Xlibris have wide diffusion across all library types.

\subsection{Top-ranked libraries and self-publisher titles}

The 25 top-ranked ARL libraries held 1,056 self-publisher titles (7.5\%) from the seven self-publishers (see Table 13). In addition, these 25 ARL libraries held more titles from Xlibris (411) and AuthorHouse (326) than from the remaining five self-publishers. The 25 largest public libraries in the United States (as measured by total number of holdings) held 2,306 self-publisher titles (16.4\%). By a large margin, these 25 public libraries favor titles published by AuthorHouse (816), with titles published by iUniverse (488) and Xlibris (480) a distant second and third. Together, these 50 major academic and public libraries hold $23.9 \%$ 
of the total number of 14,061 self-publisher titles identified in the present study and favor, in descending order, AuthorHouse, Xlibris, and iUniverse.

There were important differences in the nature of the self-published titles that top-ranked ARL libraries and top-ranked public libraries had in their collections. For example, there were no common titles among the top five iUniverse titles held by top-ranked ARL and public libraries. The top five iUniverse titles held by the top 25 public libraries included If I Knew Then, The Chinese Adoption Handbook, The Russian Adoption Handbook, and The Great Garage Sale Book, while the top five iUniverse titles held by the 25 top-ranking ARL libraries included Research Strategies: Finding Your Way through the Information Fog, Beyond the Answer Sheet: Academic Success for International Students, The International Student's Survival Guide to Law School in the United States, and Others: Third Party Politics from Nation's Founding to the Rise and Fall of the Greenback-Labor Party. Compare also the differences in the top three titles published by PublishAmerica that were held by the top 25 public libraries-How to Destroy a Village: What the Clintons Taught a Seventeen Year Old; Science vs. Religion: The 500-year War: Finding God in the Heat of the Battle; and The Adventures of Coker LaRue - with the top three titles published by PublishAmerica that were held by the 25 top-ranked ARL libraries: Domestic Abuse: Our Stories; Rescued by a Cow and a Squeeze: Temple Grandin; and Will the Gay Issue Go Away?: Questioning Sexual Myths: Toward a New Theological Consensus on Sexual Orientation. There were, however, similarities in collecting patterns between the 25 topranked public libraries and the 25 top-ranked ARL libraries in the case of self-published titles from AuthorHouse. Three books-The Guide to Identity Theft Prevention; Measuring Sky without Ground: Essays on the Goddess Kali, Sri Ramakrishna and Human Potential; and A Genealogical Index to the Guides of the Microfilm Edition of Records of Ante-bellum Southern Plantations from the Revolution through the Civil War-were among the top five titles from this publisher held by both top-ranking ARL and public libraries. Such crossover appeal between academic and public libraries may be one reason that AuthorHouse titles are so widely available in libraries.

Were there differences in the self-publisher holding patterns of the top 25 ARL libraries and top 25 public libraries, on the one hand, and all academic libraries (universities, colleges, and community colleges considered as a group) and all public libraries, on the other? As shown in Table 14, the 25 top-ranking ARL libraries, as a percentage of their total holdings of self-publishers, held AuthorHouse titles at a rate of 30.9\%, while the comparable figure for all academic libraries was $23 \%$. The top 25 public libraries, as a percentage of their total holdings of self-publishers, held AuthorHouse titles at a rate of $35.4 \%$, while the comparable figure for all public libraries was $18 \%$. If holding rates are a proxy for publisher reputation, the reputation of AuthorHouse is higher at both the 25 top-ranking ARL and public libraries than at academic and public libraries in general. However, the reputations of PublishAmerica, Ivy House, and Vantage Press are slightly lower at both the 25 top-ranking ARL and public libraries than at academic and public libraries in general. The reputations of Dorrance, iUniverse, and Xlibris are variable, depending on whether one is comparing the 25 topranking ARL libraries with all academic libraries, or the top 25 public libraries with all public libraries. 
Table 9

Number of OCLC-member libraries holding the overall top 25 held titles published by seven American selfpublishers by type of library

\begin{tabular}{|c|c|c|c|}
\hline Type of library & Description & $\begin{array}{l}\text { Acronym used } \\
\text { in Tables } 10-12\end{array}$ & No. $(\%)$ \\
\hline Public & $\begin{array}{l}\text { Libraries designed as PUB, MEM, CNTY, } \\
\text { or REG by OCLC, as well as public } \\
\text { library consortia and school libraries }\end{array}$ & PUB & $5150(57.6)$ \\
\hline University & $\begin{array}{l}\text { Libraries designated as UNIV by OCLC, } \\
\text { as well as law and medical school libraries }\end{array}$ & UNIV & $2008(22.5)$ \\
\hline Community college & $\begin{array}{l}\text { Libraries designated as COMMUN COL } \\
\text { by OCLC, as well as technical colleges } \\
\text { and junior colleges }\end{array}$ & $\mathrm{CC}$ & $646(7.2)$ \\
\hline College & $\begin{array}{l}\text { Libraries designated as COL by OCLC, } \\
\text { as well as seminaries and religious colleges } \\
\text { (all COLs checked to see whether they were } \\
\text { in fact a COL or COMMUN COL) }\end{array}$ & $\mathrm{COL}$ & $569(6.4)$ \\
\hline Military & $\begin{array}{l}\text { Libraries at military-controlled institutions of } \\
\text { higher learning, military bases, and Veterans } \\
\text { Affairs medical centers and agencies }\end{array}$ & MIL & $252(2.8)$ \\
\hline State library & $\begin{array}{l}\text { Libraries designated by OCLC as being } \\
\text { state libraries }\end{array}$ & $\mathrm{SL}$ & $102(1.1)$ \\
\hline Government & $\begin{array}{l}\text { Libraries designed by OCLC as being national } \\
\text { depositories or pertaining to a nonmilitary } \\
\text { department or agency of a national government }\end{array}$ & GOV & $74(0.8)$ \\
\hline Historical society & $\begin{array}{l}\text { Libraries designated by OCLC as pertaining to } \\
\text { historical societies, museums, archives, } \\
\text { and art galleries }\end{array}$ & HIST & $69(0.8)$ \\
\hline Other & $\begin{array}{l}\text { Libraries pertaining to private corporations, } \\
\text { nonmilitary hospitals, law firms, banks, churches, } \\
\text { and other institutions not included in } \\
\text { any of the other categories above }\end{array}$ & OTHER & $65(0.7)$ \\
\hline Total & All libraries & Not applicable & $8935(100)$ \\
\hline
\end{tabular}

Percentages do not add to 100 due to rounding.

As shown in Table 15, there are pronounced differences in the numbers of self-published titles (2000-2004) that are held by selected top-ranking and ARL and public libraries. While the five ARL libraries all have approximately the same number of titles (between 48 and 60) from the seven self-publishers, the Chicago Public Library (CPL) has a larger collection of self-published titles (286) than the New York Public Library (173), the Los Angeles Public Library (152), the Houston Public Library (37), and the Miami-Dade Public Library (149), taken separately. However, the individual holdings of all 10 large library systems - academic and public - pale in comparison to the 937 self-published titles held by the Jacksonville (Florida) Public Library, a library whose name repeatedly appeared in the holdings lists of the titles examined in the present study. Indeed, Jacksonville Public Library's total of 937 selfpublished titles is more than three times as many as CPL, more than 15 times as many as Harvard, and just slightly less than the total of self-published titles held by the 25 top-ranked ARL libraries (1056). 


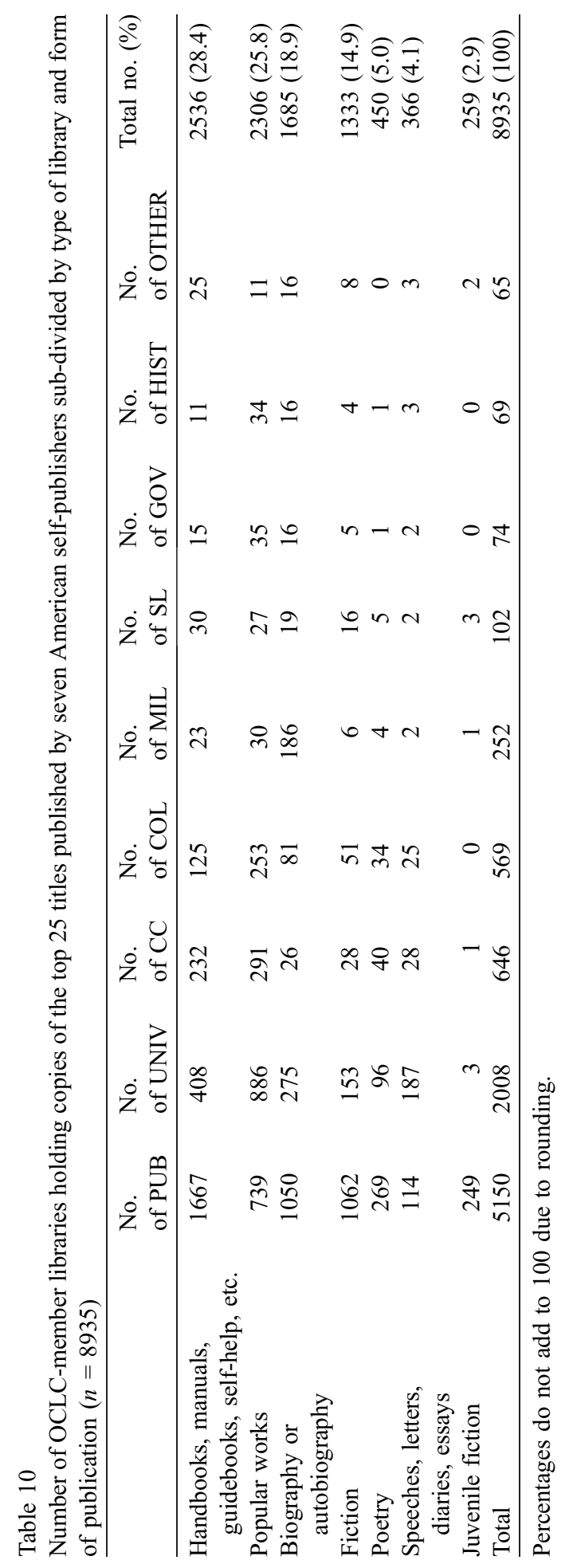




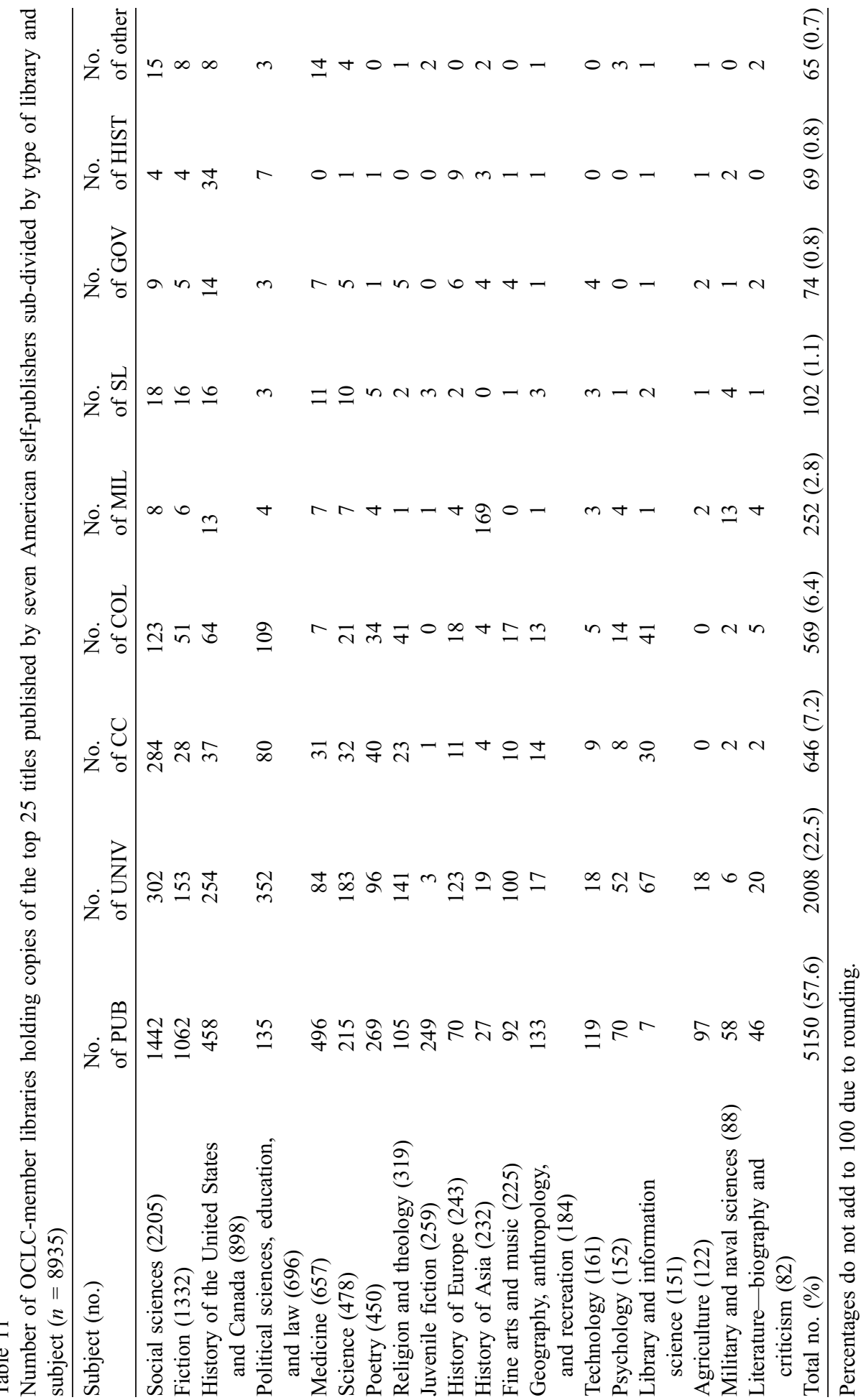




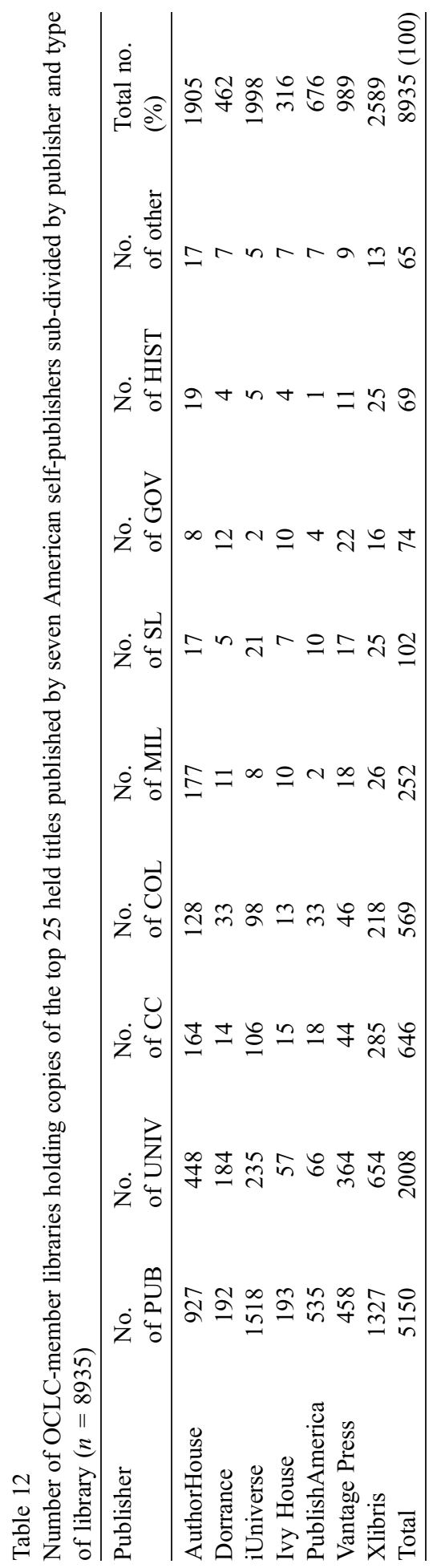


Table 13

Holdings of titles published by seven American self-publishing houses in groups of top-ranked libraries in the United States

\begin{tabular}{lccr}
\hline & $\begin{array}{l}\text { No. of titles in } \\
\text { top 25 ARL libraries }\end{array}$ & $\begin{array}{l}\text { No. of titles in } \\
\text { top 25 public libraries }\end{array}$ & $\begin{array}{l}\text { Total no. } \\
\text { of titles }\end{array}$ \\
\hline AuthorHouse & 326 & 816 & 1142 \\
Dorrance & 51 & 173 & 224 \\
iUniverse & 154 & 488 & 642 \\
Ivy House & 5 & 17 & 22 \\
PublishAmerica & 29 & 153 & 182 \\
Vantage Press & 80 & 179 & 259 \\
Xlibris & 411 & 480 & 891 \\
Total & 1056 & 2306 & 3362 \\
\hline
\end{tabular}

\section{Discussion}

Academic and public libraries are aware of titles published by self-publishers, having in their collections 14,061 unique titles published by AuthorHouse, Dorrance, iUniverse, Ivy House, PublishAmerica, Vantage Press, and Xlibris in 2000-2004. However, 42.8\% of the titles are in a single OCLC-member library, with $93.4 \%$ of the titles in fewer than 10 OCLCmember libraries each. Only a relatively small number of titles published by self-publishers (defined as those that are held by at least 10 libraries) are broadly represented in OCLCmember libraries. Possible explanations for this are: generally poor marketing on the part of self-published authors and their publishers; failure of library vendors to include selfpublishers in their approval plan profiles; lack of discounts and incentives by self-publishers to library vendors so that the vendors would include self-publishers in their approval plan

Table 14

Comparison of holdings of titles published by seven American self-publishing houses between top-ranked public and academic libraries in the United States and all public and academic libraries in the United States

\begin{tabular}{lcccc}
\hline & $\begin{array}{l}\text { No. of titles } \\
\text { in top 25 } \\
\text { ARL libraries }\end{array}$ & $\begin{array}{l}\text { No. of titles in } \\
\text { all university, college, } \\
\text { and community } \\
\text { college libraries }\end{array}$ & $\begin{array}{l}\text { No. of titles } \\
\text { in top 25 } \\
\text { public libraries }\end{array}$ & $\begin{array}{l}\text { No. of } \\
\text { titles in all } \\
\text { public libraries }\end{array}$ \\
\hline AuthorHouse & $326(30.9)$ & $740(23.0)$ & $816(35.4)$ & $927(18.0)$ \\
Dorrance & $51(4.8)$ & $231(7.2)$ & $173(7.5)$ & $192(3.7)$ \\
iUniverse & $154(14.6)$ & $439(13.6)$ & $488(21.2)$ & $1518(29.5)$ \\
Ivy House & $5(0.5)$ & $85(2.6)$ & $17(0.7)$ & $193(3.7)$ \\
PublishAmerica & $29(2.7)$ & $117(3.6)$ & $153(6.6)$ & $535(10.4)$ \\
Vantage Press & $80(7.6)$ & $454(14.1)$ & $480(7.8)$ & $458(8.9)$ \\
Xlibris & $411(38.9)$ & $1157(35.9)$ & $2306(100)$ & $1327(25.8)$ \\
Total & $1056(100)$ & $3223(100)$ & & $5150(100)$ \\
\hline
\end{tabular}

Percentages do not add to 100 due to rounding. 


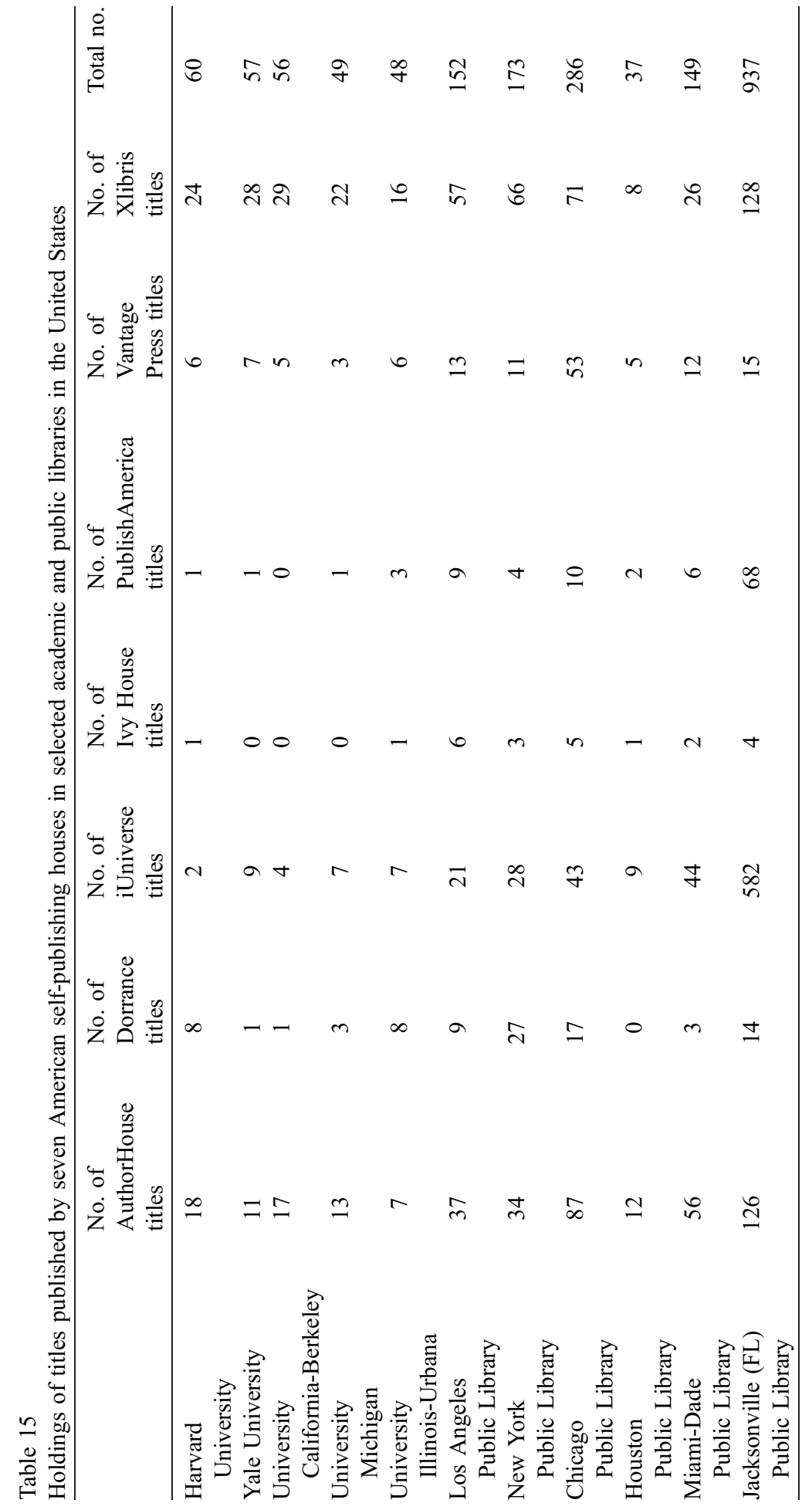


profiles; lingering concerns about the quality of titles bearing the imprint of a self-publisher; or some combination of the above.

When OCLC-member libraries do choose to collect titles from self-publishers, they are making distinctions among them, favoring AuthorHouse, iUniverse, and Xlibris (all "author services" POD publishers) rather than Dorrance, Ivy House, PublishAmerica, and Vantage Press. Given the negative publicity surrounding PublishAmerica in late 2004 and early 2005 (Span, 2005), OCLC-member libraries and librarians may not feel comfortable about the quality of titles published by PublishAmerica, nor about the older subsidy presses such as Vantage Press and Dorrance. Although AuthorHouse, among the seven self-publishers, has the greatest number of unique titles present on the shelves of all OCLC-member libraries (5223 titles, $37.1 \%$ of the total; Table 1), the rate at which its overall top 25 held titles are held by OCLC-member libraries, as a percentage of the number of OCLC-member libraries holding top 25 held titles from all seven self-publishers, no longer makes it the leading self-publisher (1905 libraries, or $21.3 \%$; Table 2). When it comes to the number of OCLC-member libraries holding top 25 held titles of self-publishers, Xlibris (2589 libraries, 29\%) and iUniverse (1,998 libraries, $22.4 \%$ ) surpass AuthorHouse. This may be an indication that OCLC-member libraries are finding that the top echelon of iUniverse and Xlibris titles is qualitatively superior to the top echelon of AuthorHouse titles - a circumstance substantiated by the fact that only iUniverse (1) and Xlibris (2) have titles that are held by 400 or more OCLC-member libraries each. However, AuthorHouse titles, as a percentage of the holdings of all seven self-publishers, are held at a proportionally greater rate by the 25 top-ranking ARL libraries and the top 25 public libraries than by all OCLC-member academic and public libraries.

In general, the better quality self-published titles may have migrated away from Dorrance and Vantage Press in 2000-2004, especially when compared with their successes (measured in terms of the numbers of OCLC-member libraries holding their most popular titles) between 1960 and 1999. Writers who may have published with Dorrance and Vantage Press in the past may now be using "author services" publishers such as AuthorHouse, iUniverse, and Xlibris. The relatively heavy rates at which OCLC-member libraries hold "author services" self-published titles, as opposed to subsidy self-publisher titles, may indicate that the titles published by "author services" self-publishers are either about topics and subjects of more interest to libraries than the titles published by subsidy self-publishers, are of a better quality, or both. In addition, the circumstance that a publisher - as in the case of AuthorHouse - has a number of titles that are judged to be worth holding by both academic and public libraries (as opposed to books that have little crossover in academic and public libraries, as in the case of iUniverse and PublishAmerica) may be another way to measure the quality (or breadth of appeal of the topic) of self-published titles, as well as the reputations of their publishers.

Based on the comparison between OCLC-member public and university libraries, on the one hand, and top-ranked ARL libraries and public libraries on the other, public libraries (no matter their ranking) hold more than twice as many self-publisher titles as academic libraries (no matter their ranking). In broad terms, academic libraries are not as receptive to self-publishers as public libraries, perhaps because of the emphasis on peer-review in the academic world. And if the Jacksonville (Florida) Public Library is any indication, some public libraries are making a 
serious effort to develop strong collections of self-publisher titles. These public libraries may have realized that the level of quality of recent self-published titles, especially from POD "author services" publishers, warrants their inclusion in library collections in significant numbers, especially in the categories of fiction and "handbooks and manuals," and in such subject areas as the social sciences, history, and medicine.

\section{Conclusion}

Library collections have always attempted to meet the needs of their users. As large mainstream publishers become focused on profit-and-loss statistics (Schiffrin, 2000) and as the demands of bookstores stoke the corporate emphasis on bestsellers (Epstein, 2001), librarians should remember that self-publishers often release titles that would not typically find a home with a profit-oriented publisher. Self-publishers may be one of the last frontiers of true independent publishing. Richard Sarnoff, the president of Random House Ventures (RHV), which owns "a minority stake in Xlibris," commenting on why RHV invested in Xlibris, explained that "[w] hat's interesting is the capability of having micro-niches that are so small that publishers would not be interested in publishing them in the traditional way" (Glazer, 2005, p. 11). Thus, micro-niche titles such as Laparoscopic Adjustable Gastric Banding and Be Brief. Be Bright. Be Gone: Career Essentials for Pharmaceutical Representatives may represent the new face of self-publishing (Glazer, 2005). If this is the direction that self-publishing is taking, public and academic librarians should reevaluate their negative preconceptions about self-publishers, especially AuthorHouse, iUniverse, and Xlibris, because catering to segmented, niche, and individualized markets has been shown, in influential marketing textbooks such as Principles of Marketing (Kotler \& Armstrong, 2003), to be an effective way to generate demand for a given product or service. In blunter terms, collection development librarians in public and academic libraries should make a conscious effort not to exclude self-published titles from their field of vision because the stigma traditionally associated with self-publishing is quickly disappearing.

\section{References}

Association of Research Libraries. (2005). ARL statistics: Ranked lists for institutions for 2003. Retrieved May 21, 2005, from http://fisher.lib.virginia.edu

AuthorHouse. (2005). Author services agreement. Retrieved June 11, 2005, from http://www.authorhouse.com/ GetPublished/Agreements.asp

Bartel, J. (2003). The Salt Lake City Public Library zine collection. Public Libraries, 42, 232-238.

Crook, M., \& Wise, N. (1987). How to self-publish and make money. Kelowna, BC: Sandhill Publishing and Crook Publishing.

Epstein, J. (2001). Book business: Publishing past present and future. New York: W. W. Norton. Glazer, S. (2005, April 24). How to be your own publisher. New York Times Book Review10-11. Hayward, P. (1992). The trend towards self-publishing. Canadian Library Journal, 49, 287-293.

Herrada, J. (1995). Zines in libraries: A culture preserved. Serials Review, 21(2), 79-88. 
Kotler, P., \& Armstrong, G. (2003). Principles of marketing (10th ed.). Upper Saddle River, NJ: Prentice Hall. Kremer, J. (1986). 1001 ways to market your books-For publishers and authors. Fairfield, IN: Ad-Lib Publications.

Kremer, J. (n.d.). The self-publishing hall of fame. Retrieved June 9, 2005, from http://www.selfpublishinghalloffame. $\mathrm{com} /$

Manley, W. (1999). One-tenth of one percent. Booklist, 96, 485.

Online Computer Library Center. (2005a). Glossary. Retrieved June 12, 2005, from http://firstsearch.oclc.org

Online Computer Library Center. (2005b). WorldCat: Window to the world's libraries. Retrieved June 12, 2005, from http://www.oclc.org/worldcat/default.htm

Public Library Association. (2004). Statistical report 2004: Public library data service. Chicago: American Library Association.

PublishAmerica. (2005). Facts and figures about one of America's most spectacular book publishing companies. Retrieved May 23, 2005, from http://www.publishamerica.com/facts/index.htm

Schiffrin, A. (2000). The business of books: How international conglomerates took over publishing and changed the way we read. London: Verso.

Span, P. (2005, January 23). Making books. Washington Post Book WorldT8-T9.

Stoddart, R., \& Kiser, T. (2004). Zines and the library. Library Resources \& Technical Services, 48, $191-198$.

Thompson, J. B. (2005, June 17). Survival strategies for academic publishing. The Chronicle of Higher Education, $51(41), \mathrm{B} 6$.

Wyatt, E. (2004, September 10). Ingredients of a best seller: Faith, luck and hard work. New York TimesE30. 